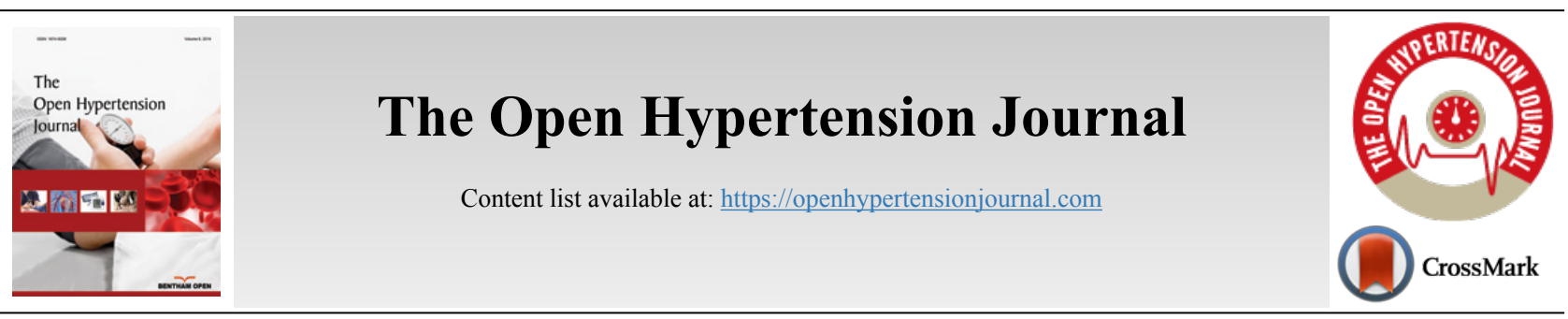

\title{
EDITORIAL
}

\section{The Coronavirus Outbreak}

\author{
Vasilios Athyros ${ }^{1, *}$ \\ ${ }^{\prime}$ Department of Internal Medicine, Aristotle University, Thessaloniki, Greece
}

Coronaviruses $(\mathrm{CoV})$ belong to a large family of viruses that cause the common cold to more severe diseases such as Middle East Respiratory Syndrome (MERS-CoV) and Severe Acute Respiratory Syndrome (SARS-CoV). A novel coronavirus $(\mathrm{nCoV})$ has recently caused a disease outbreak that affects humans. Coronaviruses have animal hosts and they are transmitted from people to people, mainly through the respiratory system.

Common signs of the disease are respiratory symptoms, fever, cough, shortness of breath and breathing difficulties. nCoV can also cause pneumonia, severe Acute Respiratory Syndrome (ARS), renal failure and finally, death. The suggestions to prevent the spread of infection include regular hand washing, the use of mouth and nose masks, avoiding close gatherings, crowds and people who show symptoms of respiratory infection.

At present, there are 71,442 coronavirus cases:, 1,776 deaths, 11,284 recovered, 58,382 currently infected patients, and 13,060 cases which had an outcome [1].

\footnotetext{
* Address correspondence to this author at the Department of Internal Medicine,
} Aristotle University, Thessaloniki, Greece; Email: vathyros@gmail.com
Currently, there is no vaccine to prevent coronavirus disease 2019 (COVID-19), and is expected to be ready within 18 months. However, as a reminder, the Center for Disease Control suggests preventive measures to prevent the spread of these respiratory diseases by avoiding close contact with people who are sick from the virus, wearing mouth and nose masks, not leaving the house if infected. The use of facemasks is also crucial for health workers and people who are taking care of someone in close settings; however, cleaning infected objects, and washing hands often with soap and water for more than $20 \mathrm{sec}$, especially prior to eating, and after blowing nose, coughing, or sneezing are also significant. An alcohol-based hand sanitizer can be used, with at least $60 \%$ alcohol. Always wash hands with soap and water, if hands are visibly dirty, use alcohol for cleaning your hands. There is no causal specific treatment, however, only symptomatic treatment is known. For severe cases of the disease, treatment should include care to support vital organs avoiding total organ failure. People who think they may have been exposed to the virus should contact the authorities and their doctor [2].

\section{REFERENCES}

[1] WHO instructions 17/02/2020. Available at: https://www.who.int/ emergencies/diseases/novel-coronavirus-2019/events-as-they-happen

[2] Center for Disease Control 17/02/2020. Available at: https://www. cdc.gov/

This is an open access article distributed under the terms of the Creative Commons Attribution 4.0 International Public License (CC-BY 4.0), a copy of which is available at: https://creativecommons.org/licenses/by/4.0/legalcode. This license permits unrestricted use, distribution, and reproduction in any medium, provided the original author and source are credited. 